\title{
Antioxidant and anti-inflammatory potentials of Solanum pubescens Willd an ethnomedicinal plant of South Western Andhra Pradesh, India
}

\author{
Haseebur RAHMAN 1 * (D), Nazneen RAHMAN 1 (D), Mir HARIS ${ }^{1}$ (D), Riaz MAHMOOD ${ }^{1}$ (D) \\ 1 Department of Biotechnology and Bioinformatics, Jnanasahyadri, Kuvempu University, Shankaraghatta - 577451 , \\ Shimoga Dist. Karnataka. INDIA. \\ * Corresponding author. E-mail address: hrehaman.2003@gmail.com (H.R.); Tel. +91 9620981880.
}

Received: 02 April 2018 / Revised: 03 September 2018 / Accepted: 23 September 2018

\begin{abstract}
Solanum pubescens Willd is an essential ethnomedicinal plant in treatment of hemorrhoids, inflammation, cancer, whooping cough, rheumatoid arthritis, liver disorders, diarrhea, headache, menstrual pain, tuberculosis, ulcers, and belongs to Southern states of India. Henceforth, to validate its medicinal uses concerning the inflammation management the current study aims to evaluate the acute toxicity, in vitro antioxidant efficacy and in vivo anti-inflammatory action of hexane and chloroform extracts of S. pubescens fruits and stem in carrageenan and cotton pellet-induced inflammation in rats. The investigations revealed that the S. pubescens fruit essential oil (SPFO), S. pubescens fruit chloroform extract (SPFC), S. pubescens stem hexane extract (SPSH) and S. pubescens stem chloroform extract (SPSC) demonstrated substantial 2,2diphenyl-1-picrylhydrazyl (DPPH), hydroxyl radicles $\left(\mathrm{OH}^{\bullet}\right)$, superoxide anion radicles (SOR), nitric oxide radicles (NOR), 2,4,6-tripyridyl-s-triazine (TPTZ) radicle scavenging effect, lipid peroxidation inhibition, total reducing power and total antioxidant activity. The extracts treatment $(200 \mathrm{mg} / \mathrm{kg})$ exhibited significant in vivo anti-inflammatory impact by inhibiting carrageenan-induced paw edema and the weight of cotton pellet-induced granuloma in rats. The current observations might be valuable in strengthening the ethnomedicinal use and considering $S$. pubescens as a pool of novel anti-inflammatory agents.
\end{abstract}

KEYWORDS: Solanum pubescens Willd; antioxidant; anti-inflammation; carrageenan; granuloma.

\section{INTRODUCTION}

Research on inflammation has become the attention of global scientific community because of its implication in widely reporting serious human diseases. Inflammation is a body vascular, humoral and cellular protective response to harmful stimuli, such as physical trauma, chemical exposure, infection and oxidative stress accompanying with progressive release of various inflammatory mediators $[1,2,3]$. Several inflammatory diseases, including psoriasis, rheumatoid arthritis, asthma, allergic rhinitis, atopic dermatitis, osteoarthritis atherosclerosis, gingivitis, vascular diseases, systemic lupus erythematosus, inflammatory bowel disease, ankylosing spondylitis, depression, and cancer are associated with the excess production of these inflammatory mediators [2, 4]. Non-steroidal anti-inflammatory (NSAIDs) are the clinically important anti-inflammatory medicines inhibiting the cyclooxygenase enzyme, while they have known to exhibit adverse side effects such as gastric disorders, cardiac disorders, hepatotoxicity and sudden cardiac death [4]. Therefore, constant research is needed to develop new anti-inflammatory agents devoid of these side effects. It is well established that medicinal plants are consistently explored for their therapeutic potentials from ages. Preclinical and clinical studies on various medicinal plants and their phytoconstituents have reported for exhibiting potential anti-inflammatory activities in the management of complex conditions like psoriasis and cancer [5-9].

Solanum pubescens Willd is an annual erect, unarmed (prickles) shrub, up to $1.5 \mathrm{~m}$ tall. Flowering and fruiting occur during the months of July-February growing abundantly in the hills of Rayadurg and other parts of Andhra Pradesh, Tamil Nadu and Kerala, India. It is known as thronless turkey berry (English),

How to cite this article: Rahman H, Rahman N, Harıs M, Mahmood R. Antioxidant and anti-inflammatory potentials of Solanum pubescens Willd an ethnomedicinal plant of South Western Andhra Pradesh, India. J Res Pharm. 2019; 23 (2): 187-197. 
usthi kaai, ushtichettu, lasivuste (Telugu), cheriachundu (Malayalam), kattusundai, sundai, sundakkai (Tamil). As an herbal prescription, S. pubescens has been in use in the treatment of hemorrhoids, inflammation, cancer, whooping cough, rheumatoid arthritis, liver disorders, diarrhea, headache, menstrual pain, tuberculosis, ulcers $[10,11]$. Our former phytochemical investigations revealed the existence of has revealed that oils \& fats, alkaloids, flavonoids, carbohydrates, saponins, coumarins and phenolics in fruits and stems extracts [10] and Kumari et al., characterized the noval phytochemicals like kaermpferol-3,7,4'-trimethyl ether, quercetin-3,7,3',4'-tetramethyl ether, quercetin-3,7,3'-trimethyl ether, quercetin-3,7,4'-trimethyl ether, kaempferol-3,7-dimethyl ether, kaempferol-3,4'-dimethyl ether, myricetin-3,7,3',5'-tetrarnethyl ether. Similarly, quercetin-3,3',4'-trimethyl ether, quercetin-3,3'-dimethyl ether, kaempferol, myricetin-3,7,3'trimethyl ether, glucoside, kaempferol-3-O-rutinoside, Myricetin methyl ethers 3,7,3',5'-Tetramethoxy-5,4'dlhydroxyflavone and a novel flavonol 3,7,3'-trimethoxy-5,4',5'-trihydroxyflavone in S. pubescens [12], and it is settled that flavonoids, phenolics, and polyphenols have announced for their superb antioxidant potentials and various pharmacological properties including anti-inflammation activity [13-16]. Further, the therapeutic exploration revealed gastroprotective, antidiabetic, hepatoprotective, anti-ulcerogenic, antidiarrheal, antianxiety, anti-depressants, myorelaxant, antitumor and antibacterial activities [17], while the effects of $S$. pubescens on inflammation remain to be elucidated.

Hence, to validate the folkloric claims the present study has aimed to evaluate the acute toxicity, in vitro antioxidant potentials along with the anti-inflammatory potentials of hexane and chloroform fruits and stem extracts in carrageenan and cotton pellet induced inflammation in rats. To the best of our knowledge, the antiinflammatory, antioxidant and acute toxicity evaluation of S. pubescens fruits and stems hexane and chloroform extracts are reported for the first time through current investigations.

\section{RESULTS AND DISCUSSION}

Complex negative effect of the defense mechanism of the body against the external stimuli is called as the inflammation. The initiation of the inflammation occurs in mostly two ways i.e. either by lipoxygenase or the cyclooxygenase mechanisms, both of these mechanism are highly dependent on the amount of ROS and RNS. Hence, the evaluation of antioxidant potential along with the anti-inflammatory potential of any lead is highly sensible. The crucial function of the polyphenols and flavonoids are the inhibition of free radicles, inhibiting the chelation of ions in the active center of the enzyme and the interruption of substrate binding enzyme by disruption of the hydrogen bonding system [18].

Earlier reports regarding the effective antioxidant along with the anti-inflammatory potentials of the lipophilic flavonoids are reported [19]. Hence, the lipophilic flavonoids being main concern of the present study the non-polar solvents such as hexane and chloroform were chosen for the isolation of Solanum pubescens fruit and stem extracts. Our past investigations detailed a significant amount of total phenolic content in SPSC, SPFO, SPFC, and SPSH extracts with an amount of $98.4 \pm 0.21,95.36 \pm 0.81,91.63 \pm 0.2$, and $60.63 \pm 0.18 \mathrm{mg} / \mathrm{g}$ individually. While, SPFO was rich in flavonoids $(188.05 \pm 0.09)$ trailed by SPSC $(86.33 \pm 0.25 \mathrm{mg} / \mathrm{g})$, SPFC $(82.04 \pm 0.14)$ and SPSH $(76.08 \pm 0.09 \mathrm{mg} / \mathrm{g})$, it is noteworthy that, the fruit hexane extraction yielded oil content of about $4.94 \pm 0.1 \%$ reported to be highest amount present in solanum genus where essential oils are less frequent [10], our results are in agreement with the earlier reports describing the isolation of flavonoids and phenolics with non polar solvents like hexane and chloroform [20,21], these findings paved the way to uncover the therapeutic potentials of hexane and chloroform extracts by means of antioxidant and antiinflammatory analysis.

\subsection{In vitro antioxidant efficacy}

Tested in vitro antioxidant efficacy of $S$. pubescens hexane and chloroform extracts showed remarkable antioxidant adequacy in DPPH radicle scavenging activity, $\mathrm{OH}^{\cdot}$ radicle scavenging activity, SOR radicle scavenging activity, total reducing potentials. Similarly, the extracts also demonstrated nitric oxide radicle scavenging activity, TPTZ radicle scavenging activity, lipid peroxidation inhibition and total antioxidant activity when compared with the standard BHT and ascorbic acid as shown in Table 1 and Figure1. Among the tested extracts, SPFC showed the most astounding antioxidant activity in the order of DPPH (Figure 1A) $>\mathrm{OH}$ (Figure 1B) $>\mathrm{SOR}$ (Figure 1C) $>$ NOR (Figure 1D) $>$ LPI (Figure 1F) with an $\mathrm{IC}_{50}$ of $70.65 \pm 0.45,71.53 \pm 0.55$, $159 \pm 0.67,195 \pm 2.32$ and $84.2 \pm 0.79 \mu \mathrm{g} / \mathrm{ml}$ respectively (Table 1). Interestingly all the extracts were substantially active in the total reducing power model (Figure 1E). While among the tested extracts SPSC was 

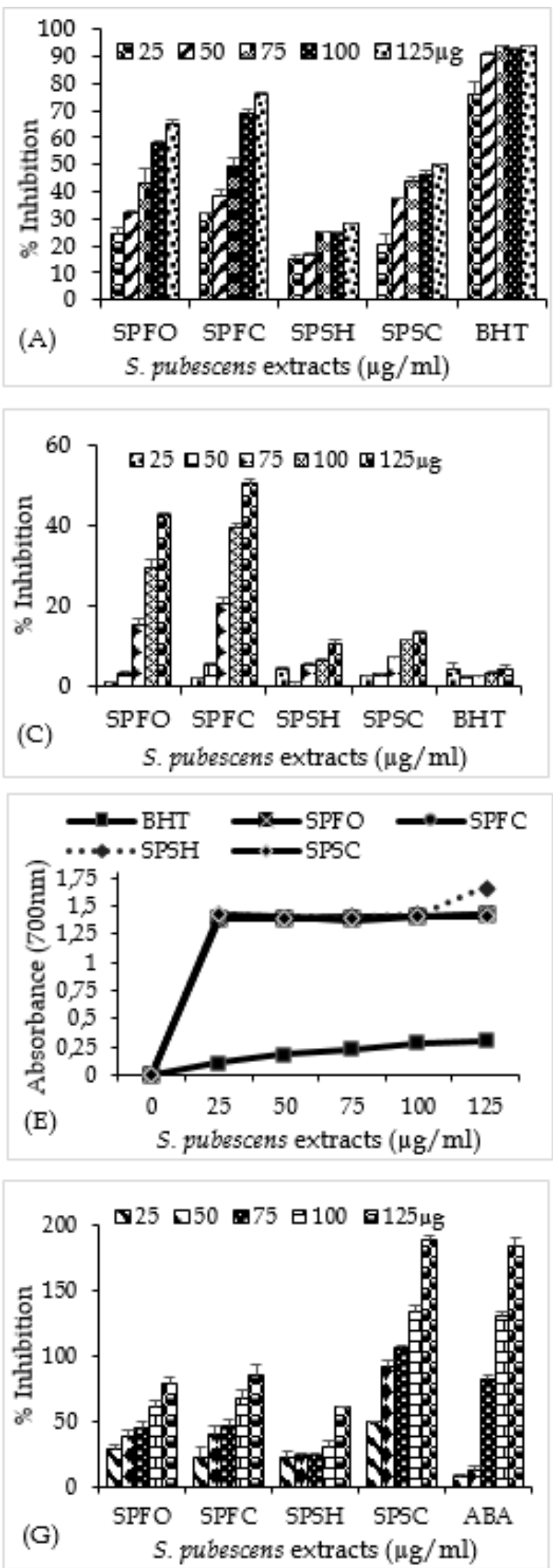
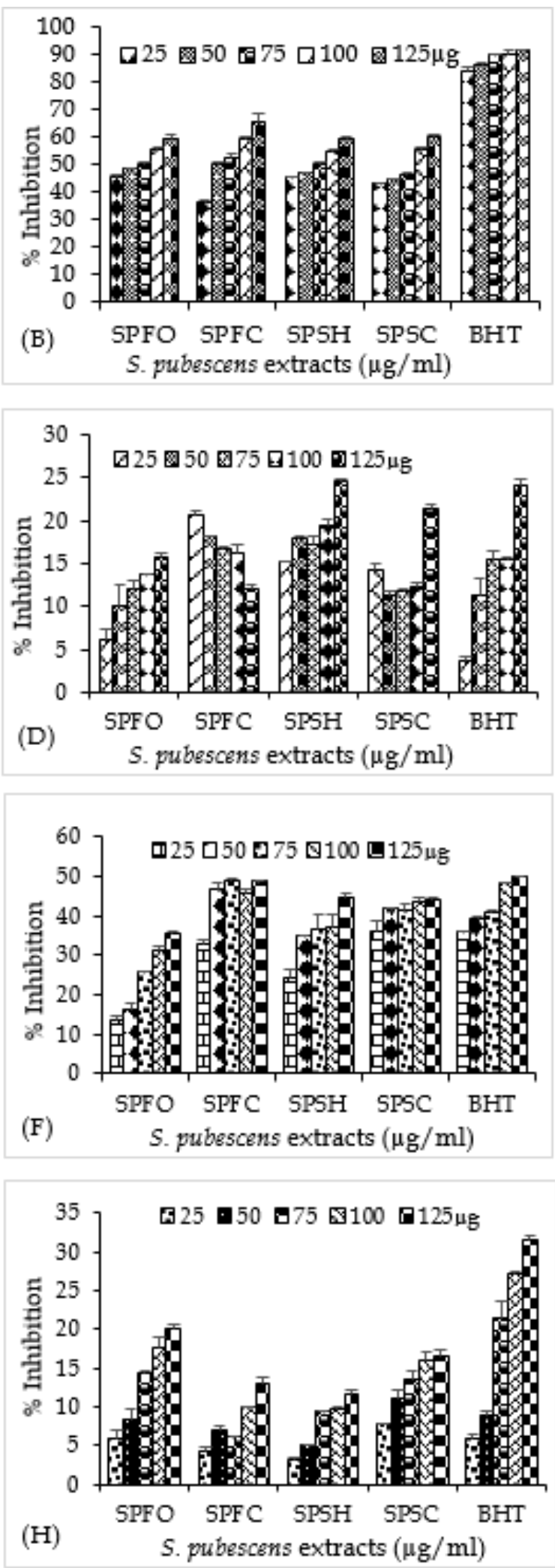

Figure 1. In vitro antioxidant effect of S. pubescens extracts. (A): DPPH radical-scavenging activity, (B): Hydroxyl radical scavenging activity, (C): Superoxide anion scavenging activity, (D): Nitric oxide radical scavenging activity, (E): Total reducing power, (F) Lipid peroxidation inhibition, $(\mathrm{G})$ : Ferric reducing antioxidant power (FRAP), $(\mathrm{H})$ : Total antioxidant capacity. The values are mean $\pm \mathrm{SEM}$, are averages of three independent experiments. 
more active in the TPTZ assay model as shown in Figure $1 \mathrm{G}$ with $\mathrm{IC}_{50}$ of $32.85 \pm 0.92 \mu \mathrm{g} / \mathrm{ml}$ (Table 1 ). Whereas, the total antioxidant assay model (Figure $1 \mathrm{H}$ ) revealed the potency of SPFO with an $\mathrm{IC}_{50}$ of $283.27 \pm 0.24$ when compared with the respective standards as indicated in Table 1. ROS and RNS factor even though these molecules involve in the accretion of macrophages and settling of inflammatory cells to their respective positions, when surpassed may also be responsible for the delayed salvation of wounds by persuading tissue damage [22]. The inhibition of respective free radicles speak to the capacity of S. pubescens fruit and stem hexane and chloroform extracts enriched with diverse phytochemicals and considerable amount of flavonoids and phenolics to apply the potential antioxidant action and this therapeutic action can be credited to exert profound anti-inflammatory activity, as it is recognized that the free radicle scavenging potentials protects the CNS and ultimately triggers the pain reduction and tissue damage derived from lipid peroxidation at the inflamed site [23, 24].

Table 1. $\mathrm{IC}_{50}$ values of $S$. pubescens successive solvent extracts for In vitro antioxidant activities.

\begin{tabular}{|c|c|c|c|c|c|c|}
\hline $\begin{array}{l}\text { Sl. } \\
\text { No. }\end{array}$ & Activity & SPFO $(\mu \mathrm{g})$ & SPFC $(\mu \mathrm{g})$ & SPSH $(\mu \mathrm{g})$ & SPSC $(\mu \mathrm{g})$ & $\begin{array}{l}\text { Standard } \\
(\mu \mathrm{g})\end{array}$ \\
\hline 1 & $\begin{array}{l}\text { DPPH radical scavenging } \\
\text { activity }\end{array}$ & $84.17 \pm 0.72$ & $70.65 \pm 0.45$ & $172 \pm 3.27$ & $94.7 \pm 0.33$ & $41.9 \pm 0.49$ \\
\hline 2 & $\begin{array}{l}\text { Hydroxyl radical } \\
\text { scavenging activity }\end{array}$ & $72.9 \pm 0.18$ & $71.53 \pm 0.55$ & $73.6 \pm 0.15$ & $73.6 \pm 0.15$ & $42.6 \pm 0.07$ \\
\hline 3 & $\begin{array}{l}\text { Superoxide radical } \\
\text { scavenging activity }\end{array}$ & $204.9 \pm 0.30$ & $159 \pm 0.67$ & $677 \pm 3.49$ & $503 \pm 1.8$ & $146.87 \pm 2.09$ \\
\hline 4 & $\begin{array}{l}\text { Nitric oxide radical } \\
\text { scavenging activity }\end{array}$ & $324.34 \pm 0.39$ & $195 \pm 2.32$ & $199 \pm 3.42$ & $263 \pm 4.8$ & $268 \pm 12.8$ \\
\hline 5 & $\begin{array}{l}\text { Lipid peroxidation } \\
\text { inhibition }\end{array}$ & $175.96 \pm 0.34$ & $84.2 \pm 0.79$ & $106.1 \pm 5.03$ & $90.79 \pm 2.56$ & $87.55 \pm 0.38$ \\
\hline 7 & $\begin{array}{l}\text { TPTZ radical scavenging } \\
\text { activity }\end{array}$ & $71.53 \pm 0.83$ & $64.05 \pm 0.62$ & $115 \pm 3.98$ & $32.85 \pm 0.92$ & $46.19 \pm 3.10$ \\
\hline 8 & Total antioxidant assay & $283.27 \pm 0.24$ & $469.2 \pm 11.29$ & $481.3 \pm 11.34$ & $287.5 \pm 7.70$ & $198.2 \pm 2.84$ \\
\hline
\end{tabular}

\subsection{Acute toxicity studies}

The S. pubescens hexane and chloroform extract treated rats displayed no behavioral indications of harmfulness until the finish of the investigation. The acute toxicological examination advocates, that the SPFO, SPFC, SPSH and SPSC extracts were seen to be non-harmful and safe, accordingly, the $\mathrm{LD}_{50}$ of these extracts was assessed to be more than $2000 \mathrm{mg} / \mathrm{kg}$.

\subsection{Anti-inflammatory potentials}

\subsubsection{Carrageenan-induced paw edema}

S. pubescens fruit and stem hexane and chloroform extracts portrayed substantial anti-inflammatory activity against carrageenan induced acute paw inflammation as represented in Figure 2 and Figure 3 . Where the control group evidenced about $25.81 \pm 0.58 \%$ of inflammation even $240 \mathrm{~min}$ after inflammation induction. Indomethacin a viable prostaglandin inhibitor as a reference standard $(10 \mathrm{mg} / \mathrm{kg})$ demonstrated the antiinflammatory effect and inhibited $88.61 \%$ edema at $240 \mathrm{~min}$. Among the extracts $(200 \mathrm{mg} / \mathrm{kg}$ ) treated groups SPSC treatment exhibited remarkable $73.56 \%$ inhibition of edema in rats $(\mathrm{P}<0.0001)$ followed by SPFO 71.48\% $(\mathrm{P}<0.0001)$, SPFC 68.33\% (P < 0.0001) and SPSH 49.65\% ( $\mathrm{P}<0.0001)$ at $240 \mathrm{~min}$. While the standard drug indomethacin witnessed $88.61 \%$ of inhibition $(\mathrm{P}<0.0001)$ and $6.15 \pm 0.38 \%$ paw edema at the end (Figure 3 ).

The mechanism of extract treatment on inflammation stimuli created by carrageenan and the mode of action of Indomethacin superimposes on each other, which eventually instincts towards the inhibition of prostaglandins secretions [23], this further accommodates prostaglandin mediated S. pubescens antiinflammation action. Moreover, the assessment of erythrocyte sedimentation rate (ESR) of carrageenaninduced inflammation in rats uncovered that carrageenan has driven the ESR level to $4 \pm 0 \mathrm{~mm} / \mathrm{h}$. The treatment of $S$. pubescens extracts SPFO, SPFC, SPSH, and SPSC at $200 \mathrm{mg} / \mathrm{kg}$ has expressively normalized the ESR to control level $(P<0.05)$ (Figure 3), this further potentiates the therapeutic efficacy of $S$. pubescens and could be considered as a novel leads of anti-inflammatory drug development to reduce the ESR associated with infectious diseases, autoimmune diseases like psoriasis, malignancy and other ailments affecting plasma proteins and the sedimentation rate [25]. Additionally, the Pearson correlation analysis between inflammation inhibition and ESR among treated groups demonstrate significant negative correlation, which additionally 
approves the anti-inflammatory potentials, which were almost comparable to standard medication indomethacin as represented in Figure 4.

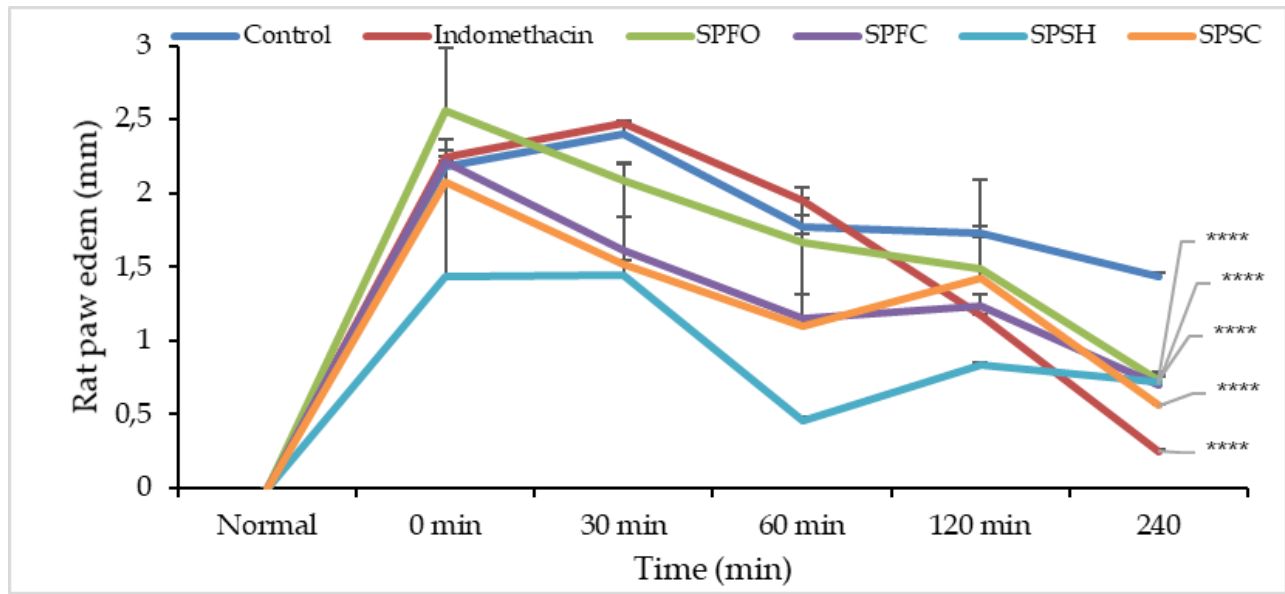

Figure 2. Anti-inflammatory potentials of S. pubescens extracts against carrageenan induced paw edema.

\subsubsection{Cotton pellet-induced granuloma}

The investigation additionally expands the profound anti-inflammatory potentials registered against cotton pellet-induced chronic inflammation as tabulated in Table 2. Compared to standard medication naproxen, all of the tested S. pubescens extracts witnessed a potential anti-inflammatory effect at the dose of $200 \mathrm{mg} / \mathrm{kg}(P<0.001)$. Among them, the SPSC extract showed the maximum granuloma inhibition of $55.13 \%$ $(P<0.001)$ followed by SPFO $(P<0.001)$, SPFC $(P<0.001)$ and SPSH $(P<0.001)$ extract. The substantial limitation of granuloma tissue development in the S. pubescens fruits and stems extracts treated rats verifies its possibilities to battle chronic inflammatory state, because of fizzled response of pro-inflammatory agents elimination by controlling fibroblast, granulocyte invasion, collagen and mucopolysaccharide synthesis and angiogenesis, evidenced by the reduction of wet weight and dry weight of the cotton pellet which designates the inhibitory potentials of $S$. pubescens fruits and stems extracts against transudative and proliferative phase of inflammation $[23,26]$. Furthermore, the study demonstrated unaltered body weight among the extract treated groups compared to control animals showing the nontoxic nature of the S. pubescens extracts.

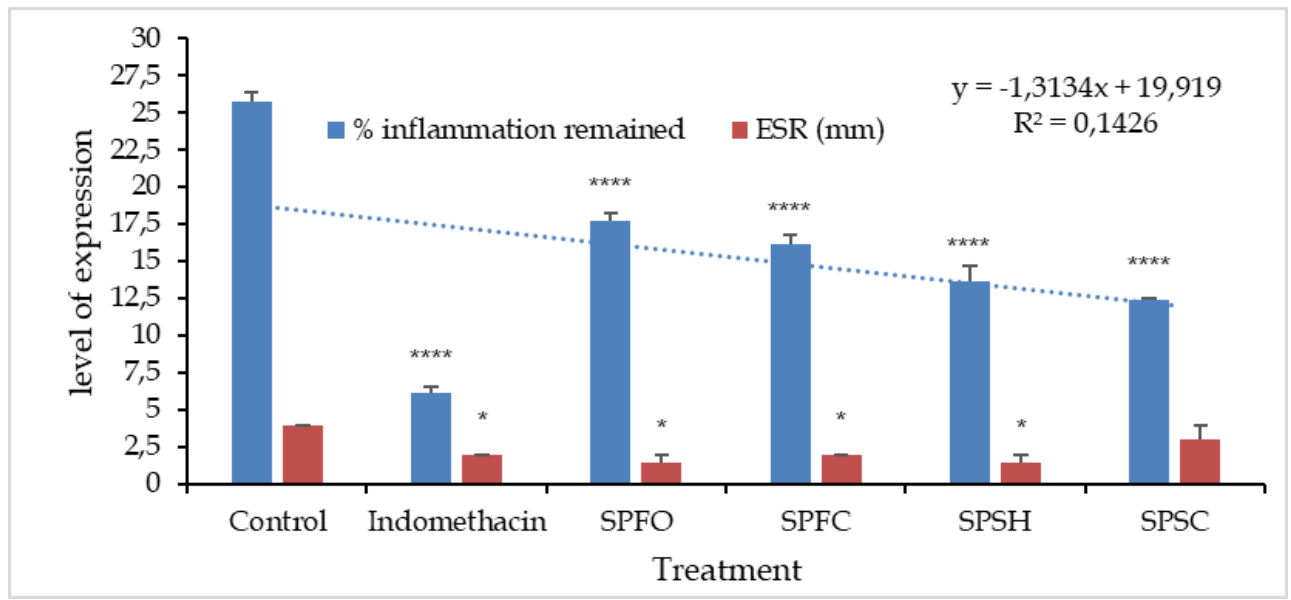

Figure 3. Effect of S. pubescens extracts in management of inflammation against carrageenan induced paw edema.

It is noteworthy that the observed anti-inflammatory properties of $S$. pubescens fruit and stem extracts for both acute and chronic inflammatory models is credited to defensive ability of phytochemicals present essentially flavonoids and its derivatives [10, 12-16, 22], most likely regulate through antioxidation action, and 
proinflammatory molecules production [8, 16, 23-25]. In addition, the current investigations approves the $S$. pubescens as potential source of anti-inflammatory agents among Solanum genus as the S. pubescens hexane and chloroform extracts at $200 \mathrm{mg} / \mathrm{kg}$ demonstrated remarkable activity when compared with the plants like S. aethiopimcum, S. xanthocarpum, S. scabrum and S. lycopersicum have been therapeutically explored for their anti-inflammatory potentials [26, 27-29].

Table 2. Anti-inflammatory effect of S. pubescens extract on cotton pellet-induced granuloma in rats.

\begin{tabular}{|c|c|c|c|c|c|c|}
\hline \multirow[b]{2}{*}{ Group } & \multicolumn{3}{|c|}{ Body weight parameters (g) } & \multicolumn{3}{|c|}{ Granuloma tissue (g/100g b. wt.) } \\
\hline & $\begin{array}{c}1^{\text {st }} \text { Day body } \\
\text { wt. }\end{array}$ & $\begin{array}{c}10^{\text {th }} \text { Day body } \\
\text { wt. }\end{array}$ & $\begin{array}{l}\% \text { Increase in } \\
\text { body weight }\end{array}$ & $\begin{array}{l}\text { Wet weight of } \\
\text { tissue }\end{array}$ & $\begin{array}{c}\text { Dry weight of } \\
\text { the }\end{array}$ & $\begin{array}{c}\% \\
\text { Inhibition }\end{array}$ \\
\hline 1 & $184 \pm 1$ & $212 \pm 2.09$ & $13.2 \pm 0.34$ & $0.544 \pm 0.03$ & $0.117 \pm 0.01$ & - \\
\hline 2 & $184.5 \pm 1.5$ & $211 \pm 1.53$ & $12.56 \pm 0.29$ & $0.318 \pm 0.02 * * *$ & $0.066 \pm 0.000 * * *$ & 43.58 \\
\hline 3 & $183 \pm 0$ & $211 \pm 2.17$ & $13.26 \pm 0.82$ & $0.27 \pm 0.01 * * *$ & $0.054 \pm 0.001 * * *$ & 53.85 \\
\hline 4 & $187 \pm 1$ & $216 \pm 2$ & $13.42 \pm 0.34$ & $0.31 \pm 0.12 * * *$ & $0.058 \pm 0.000 * * *$ & 50 \\
\hline 5 & $183 \pm 0.5$ & $220 \pm 1$ & $13.63 \pm 1.25$ & $0.295 \pm 0.005 * * *$ & $0.065 \pm 0.002 * * *$ & 44.44 \\
\hline 6 & $190 \pm 1$ & $219 \pm 2$ & $13.23 \pm 0.33$ & $0.265 \pm 0.025 * * *$ & $0.052 \pm 0.000 * * *$ & 55.13 \\
\hline
\end{tabular}

The values are mean \pm SEM, are averages of three independent experiments.

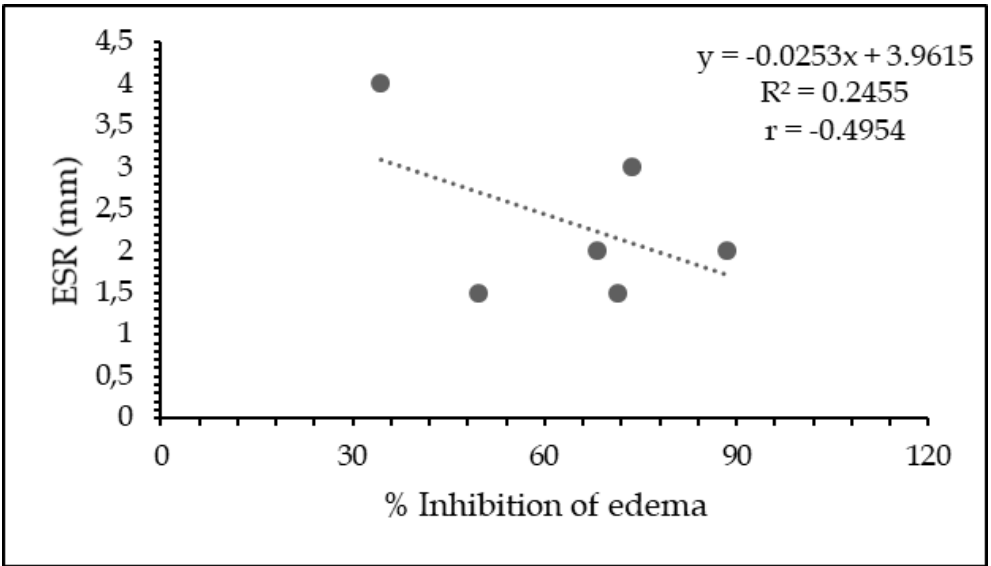

Figure 4. Represents correlational studies of ESR vs. \% inhibition of edema of S. pubescens extract against carrageenan induced inflammation.

\section{CONCLUSION}

Through present investigation, we confirm for the first time that the hexane and chloroform extracts of S. pubescens fruits and stem possess profound anti-inflammatory activities correlated with the existence of remarkable antioxidant activity, and validates the ethnomedicinal use for various inflammatory disease management. In this sense, S. pubescens can be considered as a novel source for the development of a new class of antioxidation mediated anti-inflammatory drugs.

\section{MATERIALS AND METHODS}

\subsection{Plant material and extraction}

Fresh unripe fruits and stems were collected during the month of September from Rayadurg (longitude $76^{\circ} 50^{\prime} 40.948^{\prime \prime} \mathrm{E}$ and latitude $14^{\circ} 41^{\prime} 47.288^{\prime \prime} \mathrm{N}$ ), South Western Andhra Pradesh, India. The identity of the plant was confirmed by the authentication of Prof. Pullaiah T., Taxonomist, Department of Botany, Sri Krishnadevaraya University, Anantapur, Andhra Pradesh. A Specimen of the plant was deposited under herbarium number BTRM012 at Department of Biotechnology, Kuvempu University, Karnataka.

The unripe fruits and stems were washed, shade dried and pulverized mechanically (sieve no. 10/44). The $300 \mathrm{~g}$ powdered material was subjected to Soxhlet extraction using hexane and chloroform. The extract was filtered using Buchner funnel and Whatman no. 10 filter paper and concentrated using a rotary evaporator (BUCHI, Switzerland) where fruit hexane extraction yielded greenish yellow essential oil (SPFO), while fruit 
chloroform extract (SPFC) and stem hexane extract (SPSH) and stem chloroform extract (SPSC) were powdery in nature, in light of our previous phytochemical investigations [10], the SPFO, SPFC, SPSH, and SPSC extracts were subjected to assess the antioxidant and anti-inflammatory activity.

\subsection{In vitro antioxidant activity}

\subsubsection{1,1-Diphenyl-2-picrylhydrazyl radical-scavenging activity}

The DPPH free radical rummaging capability of the extracts was determined by utilizing the revisited method of Sharma et al., [30]. Different concentrations of extracts and standard BHT $(25 \mu \mathrm{g}, 50 \mu \mathrm{g}, 75 \mu \mathrm{g}, 100$ $\mu \mathrm{g}$ and $125 \mu \mathrm{g} / \mathrm{ml}$ ) were taken and the volume was changed in accordance with $1 \mathrm{ml}$ utilizing MeOH. Newly prepared $1 \mathrm{ml}$ of $50 \mu \mathrm{M}$ DPPH solution was blended and vortexed altogether and left in dark for $30 \mathrm{~min}$. The absorbance of stable-DPPH was assessed at $517 \mathrm{~nm}$. All the while, a control without extract was readied. The radical searching action was computed utilizing the recipe: IC (\%) $=\frac{A \text { control-Atest }}{A \text { control }} \times 100$ (Eq. 1). IC $\mathrm{I}_{50}$ of extracts and standard was calculated utilizing the equation: IC50 $=\frac{\Sigma \mathrm{C}}{\Sigma I} \times 50$ (Eq. 2), where $\Sigma \mathrm{C}$ is the sum of extracts concentrations used to test and $\Sigma \mathrm{I}$ is the aggregate of the level hindrance at various concentrations.

\subsubsection{Hydroxyl radical $(\mathrm{HO} \bullet)$ scavenging activity}

The hydroxyl radical scavenging action was resolved by the modified strategy [31]. The Fenton reaction mix containing $200 \mu \mathrm{l}$ of $10 \mathrm{mM} \mathrm{FeSO}_{4} \cdot 7 \mathrm{H}_{2} \mathrm{O}, 200 \mu \mathrm{l}$ of $10 \mathrm{mM}$ EDTA and $200 \mu \mathrm{l}$ of $10 \mathrm{mM}$ 2-deoxyribose was blended with $1.2 \mathrm{ml}$ of $0.1 \mathrm{M}$ phosphate cradle ( $\mathrm{pH} 7.4)$ containing $500 \mu \mathrm{l}$ of various concentrations ( $25 \mu \mathrm{g}, 50$ $\mu \mathrm{g}, 75 \mu \mathrm{g}, 100 \mu \mathrm{g}$ and $125 \mu \mathrm{g} / \mathrm{ml}$ ) of extracts. Freshly prepared $200 \mu \mathrm{l}$ of $10 \mathrm{mM} \mathrm{H}_{2} \mathrm{O}_{2}$ was added to the blend and incubated for $4 \mathrm{~h}$ at $37^{\circ} \mathrm{C}$. Afterward, $1 \mathrm{ml}$ of $2.8 \%$ TCA and $1 \mathrm{ml}$ of $1 \%$ TBA were included and put in bubbling water for $10 \mathrm{~min}$. The mixture was brought to room temperature and centrifuged at $2000 \mathrm{rpm}$ for 5 min and absorbance was estimated at $532 \mathrm{~nm}$. The level of hydroxyl radical rummaging activity was figured by utilizing the following equation and compared with the standard BHT. The level of hydroxyl radical scavenging activity and the $\mathrm{IC}_{50}$ was calculated by utilizing the Equations 1 and 2.

\subsubsection{Superoxide anion scavenging activity}

Embracing the available strategy the superoxide anion scavenging activity was resolved [31]. A mixture of $1 \mathrm{ml}$ of NBT (156 $\mu \mathrm{M}$ NBT in $100 \mathrm{mM}$ phosphate buffer, pH 7.4) $1 \mathrm{ml}$ NADH (468 $\mu \mathrm{M}$ in $100 \mathrm{mM}$ phosphate buffer, pH7.4) and $0.1 \mathrm{ml}$ diverse concentrations $(25 \mu \mathrm{g}, 50 \mu \mathrm{g}, 75 \mu \mathrm{g}, 100 \mu \mathrm{g}$ and $125 \mu \mathrm{g} / \mathrm{ml})$ of hexane and chloroform extracts and BHT as standard was set up in water. To this mix, $100 \mu \mathrm{l}$ of PMS solution (60 $\mu \mathrm{M}$ PMS in $100 \mathrm{mM}$ phosphate buffer, $\mathrm{pH}$ 7.4) was added to begin the reaction, incubated for $5 \mathrm{~min}$ at $25^{\circ} \mathrm{C}$, and the absorbance was estimated at $560 \mathrm{~nm}$ against blank. The reduced absorbance of the reaction mixture showed expanded superoxide anion rummaging action. The inhibition (\%) and $\mathrm{IC}_{50}$ of radical scavenging action was computed utilizing the formula (1) and (2).

\subsubsection{Nitric oxide radical $(\mathrm{NO} \bullet$ ) scavenging activity}

The activity was determined by adopting the modified method [31]. $2 \mathrm{ml}$ of $10 \mathrm{mM}$ sodium

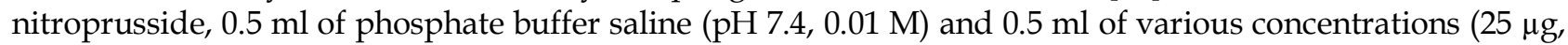
$50 \mu \mathrm{g}, 75 \mu \mathrm{g}, 100 \mu \mathrm{g}$ and $125 \mu \mathrm{g} / \mathrm{ml})$ of extracts were incubated for $150 \mathrm{~min}$ at $25^{\circ} \mathrm{C}$. The reaction mix $(0.5 \mathrm{ml})$ was blended with $1 \mathrm{ml}$ of sulphanilic acid reagent $(0.33 \%$ of every $20 \%$ glacial acetic acid) and permitted to remain for $5 \mathrm{~min}$ for the completion of diazotization response. The resultant mixture was then included with $1 \mathrm{ml}$ of naphthylethylenediamine dihydrochloride $(0.1 \%)$ and permitted to remain for $30 \mathrm{~min}$ in diffused light and read at $540 \mathrm{~nm}$ against blank. Scavenging capacity of the extract was compared with standard BHT (butylated hydroxytoluene). The level of nitric oxide radical scavenging activity and the IC50 was calculated by utilizing the formula (1) and (2).

\subsubsection{Total reducing power}

The reducing power was assessed as reported by Gouthamchandra et al., [31]. $2.5 \mathrm{ml}$ of extract $(25 \mu \mathrm{g}$, $50 \mu \mathrm{g}, 75 \mu \mathrm{g}, 100 \mu \mathrm{g}$ and $125 \mu \mathrm{g} / \mathrm{ml}), 2.5 \mathrm{ml}$ of phosphate buffer $(200 \mathrm{mM}, \mathrm{pH} 6.6)$ and $2.5 \mathrm{ml} 1 \%$ potassium ferricyanide were mixed and kept at $50{ }^{\circ} \mathrm{C}$ for $20 \mathrm{~min}$, subsequently added with $2.5 \mathrm{ml}$ of $10 \%$ TCA and centrifuged $10 \mathrm{~min}$ at $3000 \mathrm{rpm}$. Distilled water $(5 \mathrm{ml}), 1 \% \mathrm{FeCl}_{3}(1 \mathrm{ml})$ was mixed with $5 \mathrm{ml}$ supernatant and read at $700 \mathrm{~nm}$. The increase optical density of the reaction mix was interpreted as an expansion in the reducing power of the extract and compared with BHT. 


\subsubsection{Lipid peroxidation inhibition}

A modified thiobarbituric acid reactive species (TBARS) assay [32] was utilized to measure the lipid peroxide framed utilizing egg yolk homogenates as lipid-rich media. Egg homogenate $(0.5 \mathrm{ml} \mathrm{of} 10 \% \mathrm{v} / \mathrm{v})$ and $0.1 \mathrm{ml}$ of extracts $(25 \mu \mathrm{g}, 50 \mu \mathrm{g}, 75 \mu \mathrm{g}, 100 \mu \mathrm{g}$ and $125 \mu \mathrm{g} / \mathrm{ml})$ were added to a test tube and made up to $1 \mathrm{ml}$ with distilled water, $0.05 \mathrm{ml}$ of $\mathrm{FeSO}_{4}(0.07 \mathrm{M})$ was added to induce lipid peroxidation and incubated for 30 min. To the mixture, $1.5 \mathrm{ml}$ of $20 \%$ acidic acid ( $\mathrm{pH} 3.5$ ) and $1.5 \mathrm{ml}$ of $0.8 \%(\mathrm{w} / \mathrm{v})$ thiobarbituric acid in $1.1 \%$ sodium dodecyl sulfate was included, vortexed and then warmed at $95^{\circ} \mathrm{C}$ for $60 \mathrm{~min}$. Subsequent to cooling, $5.0 \mathrm{ml}$ of butanol was added to each tube and centrifuged ( $3000 \mathrm{rpm}, 10 \mathrm{~min})$. The absorbance of the organic upper layer was measured at $532 \mathrm{~nm}$. Inhibition of lipid peroxidation (\%) by the extracts was computed as $\mathrm{LPO} \%=\frac{1-\mathrm{E}}{\mathrm{C}} \times 100$ (Eq. 3). Where $\mathrm{C}$ is the absorbance value of the completely oxidized control and $\mathrm{E}$ is the absorbance of extract.

\subsubsection{Ferric reducing antioxidant power}

Ferric reducing antioxidant power (FRAP) of S. pubescens hexane and chloroform extracts was estimated accordingly [33]. Briefly, $3 \mathrm{ml}$ of preheated $\left(37^{\circ} \mathrm{C}\right)$ working FRAP reagent $(25 \mathrm{ml} 0.3 \mathrm{M}$ sodium acetate buffer (pH 3.6), $2.5 \mathrm{ml} 0.01 \mathrm{M} \mathrm{TPTZ}$ in $0.04 \mathrm{M} \mathrm{HCl}, 2.5 \mathrm{ml} 0.02 \mathrm{M} \mathrm{FeCl}_{3} .6 \mathrm{H}_{2} \mathrm{O}$ ) was mixed with $100 \mu$ lextracts at various concentrations $\left(25 \mu \mathrm{g}, 50 \mu \mathrm{g}, 75 \mu \mathrm{g}, 100 \mu \mathrm{g}\right.$ and $125 \mu \mathrm{g} / \mathrm{ml}$ ) and incubated at $37^{\circ} \mathrm{C}$ for 5 minutes. Simultaneously, a blank and standard ascorbic acid was prepared. The absorption of the blue Fe II-complex was perused spectrophotometrically at $593 \mathrm{~nm}$. The level of free radicle scavenging activity was figured by utilizing the formula (1) and (2).

\subsubsection{Total antioxidant capacity}

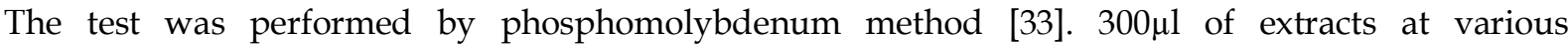
concentrations $(25 \mu \mathrm{g}, 50 \mu \mathrm{g}, 75 \mu \mathrm{g}, 100 \mu \mathrm{g}$ and $125 \mu \mathrm{g} / \mathrm{ml})$ was mixed with $3 \mathrm{ml}$ of reagent mix $(4 \mathrm{mM}$ ammonium molybdate, $0.6 \mathrm{M}$ sulfuric acid and $28 \mathrm{mM}$ of sodium phosphate). The mixture was kept for incubation at $95{ }^{\circ} \mathrm{C}$ for $90 \mathrm{~min}$, cooled and read at $695 \mathrm{~nm}$ against blank. The inhibition (\%) and $\mathrm{IC}_{50}$ of total antioxidant action were imputed utilizing the formula (1) and (2).

\subsection{Animals and study design}

Eight-week-old male Wistar albino rats (180 to $220 \mathrm{~g}$ ) were utilized. Institutional Animal Ethical Committee permitted the investigations under the certification (Ref. No. NCP/IAEC/CL/248/2013-14). All rats were kept under the consequent conditions: $25 \pm 3{ }^{\circ} \mathrm{C}, 50 \pm 10 \%$ humidity and a $12 \mathrm{~h}$ light-dull cycle, with free access to standard sustenance and water.

\subsection{Acute toxicity study}

The acute toxicity investigation of $S$. pubescens hexane and chloroform extracts was conducted as per the Organization of Economic Co-operative and Development (OECD) guideline 420 (2001). The rats have fasted overnight with free access to water. A single dosage of SPFO, SPFC, SPSH, SPSC $2000 \mathrm{mg} / \mathrm{kg}$ body weight was orally gavaged to four groups $(n=6)$ of male Wistar rats. The rats in the control group $(n=6)$ were nourished with $1 \%$ DMSO as a vehicle. All the experimental animals were kept up under close checking to observe the signs of toxicity and mortality if any, twice every day for 14 days.

\subsection{Anti-inflammatory activity}

\subsubsection{Carrageenan-induced paw edema}

The male Wistar rats (120-150 g) were divided into six groups of 6 animals each. The first control group and the second group was dosed with distilled water and indomethacin $(10 \mathrm{mg} / \mathrm{kg}$, p.o.) respectively. The rats in third, fourth, fifth, and 6th groups were treated with the SPFO, SPFC, SPSH, and SPSC extracts of 200 $\mathrm{mg} / \mathrm{kg}$ separately. The rats were pre-treated with the drug $1 \mathrm{~h}$ before the administration of carrageenan for the proper absorption of the drug in the body. Acute inflammation was triggered by the injecting $0.1 \mathrm{ml}$ of $1 \%$ carrageenan in the subplantar region of the right hind paw of the rats. The thickness $(\mathrm{mm})$ of the paw was measured immediately at 30,60, 120 and $240 \mathrm{~min}$ interval, by utilizing Vernier caliper [23]. The rate of inflammation remained was calculated by using the formula,

$$
\% \text { inflammation remained }=\frac{\mathrm{Pt} A-\mathrm{Pt} B}{\mathrm{Pt} A} \times 100
$$


The percentage inflammation inhibition was determined by the equation,

$$
\% \text { inflammation inhibition }=\frac{\mathrm{Pt} C-\mathrm{Pt} A}{\mathrm{Pt} C} \times 100
$$

Where $\operatorname{Pt} A$ is the Paw thickness at $240 \mathrm{~min}, \mathrm{Pt} B$ is normal paw thickness, $\mathrm{PtC}$ is paw thickness at 0 min of carrageenan injection.

\subsubsection{Determination of erythrocyte sedimentation rate (ESR)}

Toward the finish of the Carrageenan-incited paw edema test period, the rats were euthanized by cervical dislocation; blood was collected and utilized for erythrocyte sedimentation rate analysis by Westergren method [25]. Around $3 \mathrm{ml}$ test of blood was blended with $3.8 \%$ sodium citrate solution in the proportion of 4:1 in citrate solution. The mixing of blood was finished by pivoting the sample delicately between the palms. The blood was sucked gradually up to the mark zero in the Westergren pipette. The pipette was set upright in the stand, taking consideration that no blood escape. Toward the finish of 60 minutes, the upper level of red platelet segment was recorded and expressed as ESR $=\mathrm{x} \mathrm{mm}$.

\subsubsection{Cotton pellet-induced granuloma}

In the chronic inflammatory model, the male Wistar rats (120-150 g) were separated into six groups of 6 animals each. Cotton pellets, weighing $20 \mathrm{mg}$ each were sterilized. Under ketamine $(30 \mathrm{mg} / \mathrm{kg}$, i.p) anesthesia, the pellets were presented subcutaneously through a skin incision in the back of the rats and the incision was closed. The rats in the control group received distilled water $(10 \mathrm{ml} / \mathrm{kg}$, p.o $)$, while the second group was treated with $25 \mathrm{mg} / \mathrm{kg}$ of naproxen a standard anti-inflammatory drug. The rats of group third, fourth, fifth, and sixth were treated with $200 \mathrm{mg} / \mathrm{kg}$ of SPFO, SPFC, SPSH, and SPSC extract individually. All the groups $30 \mathrm{~min}$ after cotton pellet implantation were treated orally for 5 days. On the sixth day, the animals were sacrificed with cervical dislocation, the granulomas were expelled, weighed and dried at $60{ }^{\circ} \mathrm{C}$ for $24 \mathrm{~h}$, and the dry weights were analyzed. The difference between the initial wet weight and final dry weight was considered to be the weight of the amount of granulomatous tissue produced [23]. The rate of inflammation inhibition of granuloma tissue was figured as, \% granuloma inhibition $=\frac{\mathrm{WtC}-\mathrm{WtT}}{\mathrm{WtC}} \times 100$ (Eq. 6) where $\mathrm{WtC}$ is the weight of control granuloma tissue and $\mathrm{Wt} T$ is the weight of granuloma tissue of test group.

\subsection{Analysis of data}

The data were examined with Graph Pad Prism 6 for Windows (version 6.07). Parametric data was communicated as the mean \pm SEM. To decide the contrasts between bunches one-way analysis of variance (ANOVA). Fisher's LSD test was performed for intergroup correlations utilizing the least significant difference (LSD) at $0.05,0.001$ and 0.0001 to decide the level of significance among the different treatments.

Acknowledgement: This research did not receive any specific grant from funding agencies in the public, commercial, or not-for-profit sectors. The first author is much obliged to University Grants Commission, Govt. of India, New Delhi, for UGC-BSR Meritorious Fellowship (SRF). The authors wish to thanks to Prof. Pullaiah T., Department of Botany, Sri Krishnadevaraya University, Anantapur, Andhra Pradesh, India, for the identification of the plant material collected.

Author contributions: Author contributions: Concept - H.R., R.M.; Design - H.R., N.R.; Supervision - R.M.; Resource - H.R., R.M.; Materials - H.R. N.R.; Data Collection and/or Processing - H.R., N.R.; Analysis and/or Interpretation H.R., N.R.; Literature Search - H.R., N.R., M.H.; Writing - H.R., N.R., M.H.; Critical Reviews - H.R., N.R., R.M., M.H.

Conflict of interest statement: The authors declared no conflict of interest.

\section{REFERENCES}

[1] Young CN, Koepke JI, Terlecky LJ, Borkin MS, Boyd SL, Terlecky SR. Reactive oxygen species in tumor necrosis factor-a-activated primary human keratinocytes: implications for psoriasis and inflammatory skin disease. J Invest Dermatol. 2008; 128(11): 2606-2614. [CrossRef]

[2] Jeong YH, Oh YC, Cho WK, Lee B, Ma JY. Anti-inflammatory effects of Melandrii herba ethanol extract via inhibition of NF-kB and MAPK signaling pathways and induction of HO-1 in RAW 264.7 cells and mouse primary macrophages. Molecules. 2016; 21(6): 818. [CrossRef] 
[3] Shu Z, Xing N, Wang Q, Li X, Xu B, Li Z, Kuang H. Antibacterial and anti-inflammatory activities of Physalis alkekengi var. franchetii and its main constituents. Evidence-Based Complement Altern Med. 2016. Article ID 4359394 [CrossRef]

[4] Souza EPBSS, Faria RX, Rocha LM. Clinical trials studies of plant extracts with anti-inflammatory activity. J App Pharm Sci. 2016; 6(12): 224-232. [CrossRef]

[5] González R, Ballester I, López-Posadas R, Suárez MD, Zarzuelo A, Martinez-Augustin O, Medina FS. Effects of flavonoids and other polyphenols on inflammation. Crit Rev Food Sci Nutr. 2011; 51(4): 331-362. [CrossRef]

[6] Kaur A, Kumar S. Plants and plant products with potential antipsoriatic activity-A review. Pharm Biol. 2012; 50(12): 1573-1591. [CrossRef]

[7] Chun JM, Kim HS, Lee AY, Kim SH, Kim HK. Anti-inflammatory and antiosteoarthritis effects of Saposhnikovia divaricata ethanol extract: in vitro and in vivo studies. Evidence-Based Complement Altern Med. 2016. Article ID 1984238 [CrossRef]

[8] Boakye YD, Agyare C, Abotsi WK, Ayande PG, Ossei PP. Anti-inflammatory activity of aqueous leaf extract of Phyllanthus muellerianus (Kuntze) Exell. and its major constituent, geraniin. J Ethnopharmacol. 2016; 187: 17-27. [CrossRef]

[9] Bairagi SM, Pathan IB, Nitin NE. Analgesic and anti-inflammatory activity of crude leaf and bark extract of Lantana camara. Marmara Pharm J. 2017; 21(4): 810-817. [CrossRef]

[10] Rahman HU, Mahmood R, Haris M, Rahman N. Phytochemical profiling of successive extracts of fruit and stem bark of Solanum pubescens. Int J Pharm Pharm Sci. 2014; 6(9): 147-153.

[11] Nagaraju N, Rao KN. A survey of plant crude drugs of Rayalaseema, Andhra Pradesh, India. Journal of Ethnopharmacol. 1990; 29(2):137-158. [CrossRef]

[12] Kumari GK, Rao LJ, Rao NP. Myricetin methyl ethers from Solanum pubescens. Phytochemistry. 1984; 23(11): 27012702. [CrossRef]

[13] Wang Y, Qian J, Cao J, Wang D, Liu C, Yang R, Li X, Sun C. Antioxidant capacity, anticancer ability and flavonoids composition of 35 Citrus (Citrus reticulata Blanco) varieties. Molecules. 2017; 22(7): 1114. [CrossRef]

[14] Adhikari B, Dhungana SK, Ali MW, Adhikari A, Kim ID, Shin DH. Antioxidant activities, polyphenol, flavonoid, and amino acid contents in peanut shell. J Saudi Soc Agric Sci. 2018. [CrossRef]

[15] Middleton E, Kandaswami C, Theoharides TC. The effects of plant flavonoids on mammalian cells: implications for inflammation, heart disease, and cancer. Pharmacol Rev. 2000; 52(4): 673-751.

[16] Shaikh RU, Pund MM, Gacche RN. Evaluation of anti-inflammatory activity of selected medicinal plants used in Indian traditional medication system in vitro as well as in vivo. J Tradit Complement Med. 2016; 6(4): 355-361. [CrossRef]

[17] Rahman H, Mahmood R, Rahman N, Haris M. Antibacterial activity of Solanum pubescens-an ethnomedicinal plant from South Western region of Andhra Pradesh. Int J Appl Sci Biotechnol. 2014; 2(4): 501-509. [CrossRef]

[18] Działo M, Mierziak J, Korzun U, Preisner M, Szopa J, Kulma A. The potential of plant phenolics in prevention and therapy of skin disorders. Int J Mol Sci. 2016; 17(2):160: 1-41. [CrossRef]

[19] Hossain MA, Rahman SM. Isolation and characterisation of flavonoids from the leaves of medicinal plant Orthosiphon stamineus. Arabian J Chem. 2015; 8(2):218-21. [CrossRef]

[20] Dhawan D, Gupta J. Comparison of Different solvents for phytochemical extraction potential from Datura metel plant leaves. Int J Biol Chem. 2017;11:17-22. [CrossRef]

[21] Al-Matani SK, Al-Wahaibi RN, Hossain MA. Total flavonoids content and antimicrobial activity of crude extract from leaves of Ficus sycomorus native to Sultanate of Oman. Karbala Int J Med Sci. 2015; 1(3):166-171. [CrossRef]

[22] Rahman N, Rahman H, Haris M, Mahmood R. Wound healing potentials of Thevetia peruviana: Antioxidants and inflammatory markers criteria. J Tradit Complement Med. 2017; 7(4): 519-525. [CrossRef]

[23] Joseph JM, Sowndhararajan K, Manian S. Evaluation of analgesic and anti-inflammatory potential of Hedyotis puberula (G. Don) R. Br. ex Arn. in experimental animal models. Food Chem Toxicol. 2010; 48(7): 1876-1880. [CrossRef]

[24] Wang P, Xie K, Wang C, Bi J. Oxidative stress induced by lipid peroxidation is related with inflammation of demyelination and neurodegeneration in multiple sclerosis. Eur Neurol. 2014; 72(3-4): 249-254. 
[25] Jou JM, Lewis SM, Briggs C, LEE SH, De La Salle B, McFadden S. ICSH review of the measurement of the erythocyte sedimentation rate. Int J Lab Hematol. 2011; 33(2): 125-132. [CrossRef]

[26] Anosike CA, Obidoa O, Ezeanyika LU. The anti-inflammatory activity of garden egg (Solanum aethiopicum) on egg albumin-induced oedema and granuloma tissue formation in rats. Asian Pac J Trop Med. 2012; 5(1): 62-66. [CrossRef]

[27] More SK, Lande AA, Jagdale PG, Adkar PP, Ambavade SD. Evaluation of anti-inflammatory activity of Solanum xanthocarpum Schrad and Wendl (Kaṇțakāri) extract in laboratory animals. Anc Sci Life. 2013; 32(4): 222-226

[28] Ogunnaike BF, Okutachi IR, Anucha ES, Gbodi OO, Shokunbi OS, Onajobi FD. Comparative anti-inflammatory activities of Jatropha curcas, Ocimum gratissimum and Solanum scabrum leaves. J Nat Prod Plant Resour. 2013; 3(1): 5966.

[29] Li H, Deng Z, Liu R, Loewen S, Tsao R. Bioaccessibility, in vitro antioxidant activities and in vivo anti-inflammatory activities of a purple tomato (Solanum lycopersicum L.). Food Chem. 2014; 159: 353-360. [CrossRef]

[30] Sharma OP, Bhat TK. DPPH antioxidant assay revisited. Food Chem. 2009; 113(4):1202-1205. [CrossRef]

[31] Gouthamchandra K, Mahmood R, Manjunatha H. Free radical scavenging, antioxidant enzymes and wound healing activities of leaves extracts from Clerodendrum Infortunatum L. Environ Toxicol Pharmacol. 2010; 30(1): 11-18. [CrossRef]

[32] Dasgupta N, De B. Antioxidant activity of Piper betle L. leaf extract in vitro. Food Chem. 2004; 88(2): 219-224. [CrossRef]

[33] Alam MN, Bristi NJ, Rafiquzzaman M. Review on in vivo and in vitro methods evaluation of antioxidant activity. Saudi Pharm J. 2013; 21(2): 143-152. [CrossRef]

This is an open access article which is publicly available on our journal's website under Institutional Repository at http://dspace.marmara.edu.tr. 